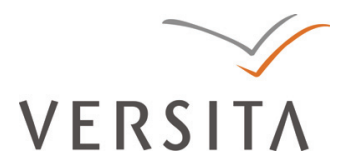

Folia Oeconomica Stetinensia

DOI: $10.2478 / \mathrm{v} 10031-012-0023-8$

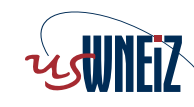

Wydzial Nauk Ekonomicznych i Zarządzania
Uniwersytetu Szczecińskiego

\title{
IMPACT OF EU ETS ON SUSTAINABLE DEVELOPMENT \\ OF ITS PARTICIPANTS IN LATVIA*
}

Ilze Prūse, MSc

Ministry of Environmental Protection and Regional Development of the Republic of Latvia

Peldu Str. 25, Riga, Latvia, LV-1494

e-mail:Ilze.Pruse@yahoo.com

Received 31 August 2012, Accepted 8 November 2012

\begin{abstract}
Latvia is covered by the European Union Emissions Trading System (EU ETS) and therein 80 participants from Latvia have participated. The goal of the paper is to analyse the impact of the EU ETS on the sustainable development of its participants in Latvia. The concept of sustainable development is explored with respect to both macro and micro scale and in the context of sustainable development the EU ETS is described. The impact of the EU ETS on its participants in Latvia is considered by means of methods of quantitative and qualitative analysis. It has been established that in past the participants of the EU ETS from Latvia had generally beneficial positions in the EU ETS; hence although the EU ETS did not directly promote greenhouse gas emission reductions, it provided opportunities to gain additional profits and many of the EU ETS participants in Latvia made use of them. In addition, certain interrelationships have been identified between the data on the EU ETS participants performing EUA trading and the data on the EU ETS participants not performing EUA trading. It has been concluded that the EU ETS might have contributed towards the sustainable development of its participants in Latvia within its certain dimensions.
\end{abstract}

Keywords: tradable permits' system, European Union Emissions Trading System, sustainable development.

JEL classification: O12, O44, Q01, Q56.

* This paper has been supported by the European Social Fund within the project „Support for Doctoral Studies at University of Latvia". 


\section{Introduction}

The European Union Emissions Trading System (EU ETS) covers around 11,000 power stations and industrial plants in 30 countries, as well as all air flights that departure from or arrive in the airports of the EU ETS member states. The EU ETS is the world's largest tradable permits' system of greenhouse gas (GHG) emission allowances, whereas a tradable permits system is an economic instrument that establishes a market of tradable permits with the aim to achieve at minimal cost the rationalization of the volumes of certain assets denoted by permits. According to the estimations of the World Bank, the value of the EU ETS transactions' main currency - European Union Allowances (EUAs) - in 2011 was 106 billion EUR ${ }^{1}$.

The purpose of this paper is to analyse the impact of the EU ETS on the sustainable development of its participants in Latvia. The main tasks of this paper are to consider the compliance of the mechanism of the EU ETS with the concept of sustainable development and to collect and analyse the relevant data with respect to the EU ETS participants in Latvia.

At the beginning of the paper the concept of sustainable development is explored with respect to macro and micro scale and the principal approach for the assessment of sustainability of the development of the EU ETS participants in Latvia is selected. Afterwards the EU ETS is described in the context of sustainable development and key indicators for the assessment of the sustainability of the development of the EU ETS participants in Latvia are determined. The significance of the EU ETS with respect to the GHG emission reduction as well as the activity of the EU ETS participants in Latvia in EUA trading is discussed. The differences between the EU ETS participants performing EUA trading and the EU ETS participants not performing EUA trading are analysed by means of methods of quantitative analysis (including dynamics analysis and correlation analysis). The quantitative analysis is supported with the results of the survey done by the author in 2011 (invitations for the participation in the survey were sent out to all participants of the EU ETS (in 2011 - 56 companies) and 35 responses were received, i.e. there was a $63 \%$ response rate). In addition, the data of sustainability indexes with respect to the EU ETS participants in Latvia is incorporated.

Taking into account the fact that the EU ETS came into operation in 2005, the principal analysis is done for the period 2005-2010. Unless specified otherwise, the analysis is based on data obtained from the official data base about companies registered in Latvia - Lursoft, the official website of the EU ETS and the official website of its Community Transaction $\log$ (CTL), the leading provider of carbon credits markets' news and research - Thomson Reuters Point Carbon as well as the annual reports of installations participating in the EU ETS 
as published on the website of the Latvian Environment, Geology and Meteorology Centre (LVGMC). The author has considered the EU ETS impact on its direct participants (owners of permits - potential sellers and buyers of permits). As conditions of transactions within the EU ETS are confidential, the author assumes that the price of EUA is equal to the average price of EUAs spot and forward prices at the date of respective transaction. Notwithstanding the fact that on 30 May 2011 the European Commission filed an appeal, recognising a fact that the ruling of the Court of Justice of the European Union dated 22 March 2011 has been followed and Latvia has received 14.3 million additional EUAs, the analysis herein is performed with due regard to that ${ }^{2}$.

\section{The Concept of Sustainable Development}

Pursuant to the most widely accepted definition, sustainable development is the development that meets the needs of the present without compromising the ability of future generations to meet their own needs ${ }^{3}$. Though some authors identify four dimensions of the sustainable development (e.g. J. Spangenberg emphasises the dimension of institutional aspects ${ }^{4}$, European Commission includes the dimension of meeting international responsibilities ${ }^{5}$ ), mostly authors distinguish three dimensions of the sustainable development - environmental, social and economic and this is an approach supported also by the author.

The concept of the sustainable development usually is attributed towards the development of states or their regions (macro-scale); however, recognising that the development of states depends on the development of its companies, the author acknowledges that the concept of the sustainable development can be used also at micro-scale.

In order to assess the sustainability of the development at macro-scale a set of macro indicators can be used. To consider local circumstances these indicators are usually determined and/or developed specifically for each particular situation. For example, for the purposes of assessing the progress towards the sustainable development in the European Union more than 100 indicators are used $^{6}$. But there are also some examples of indexes that include a set of indicators related to the sustainable development, e.g. the Human Development Index developed by United Nations Development Programme ${ }^{7}$, the Environmental Sustainability Index and the Environmental Performance Index developed by Yale University and Columbia University ${ }^{8}$, etc. There are also some indexes to assess the sustainability at micro-scale and the most popular ones are the Dow Jones Sustainability Indexes (DJSI). However, it is important to note that the DJSI are largely based on the results of questionnaires (mostly self-evaluation) and are 
considering rather corporate sustainability than sustainable development in general, provided that corporate sustainability is a business approach to create long-term shareholder value by embracing opportunities and managing risks deriving from economic, environmental and social developments ${ }^{9}$. Therefore, for the purpose of this paper and in order to assess the sustainability of the development of the EU ETS participants in Latvia the author will primary use indicators that are selected considering the specific aspects of the operation of the EU ETS. Further in this paper information from the indexes will be used as a supplementary one.

\section{The EU ETS in the Context of the Sustainable Development}

The overall goal of the EU ETS is to promote the reductions of GHG emissions in a costeffective and economically efficient manner ${ }^{10}$. However, acknowledging that the reductions of GHG emissions might be achieved also by other economic, fiscal or financial tools, the most common of which are taxes, within the context of the sustainable development the author would like to discuss also the secondary goals of the EU ETS (Figure 1).
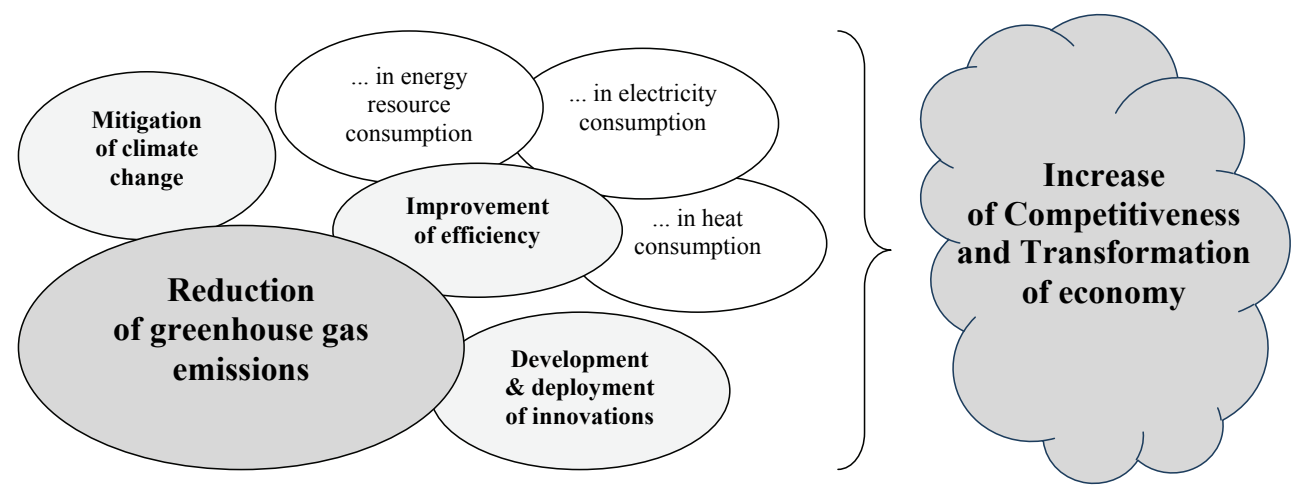

Fig. 1. The framework of the secondary goals of the EU ETS Source: created by author.

Generally the need for the reduction of GHG emissions is determined by the need to mitigate climate change (global warming). However, in parallel, the EU ETS also strongly promotes the improvements of efficiency in fossil energy resource consumption as well as in electricity and heat energy consumption as a side-effect of active emission reductions. Moreover, the EU ETS also encourages the development and deployment of new technologies ensuring more and more improvements of efficiency. Thereby, in fact, the EU ETS not only promotes the 
reduction of GHG emissions and mitigation of climate change but also ensures the increase of competitiveness and transformation of economy to "green economy"/"low emission economy". Climate change is critical for the survival of humankind; therefore, its mitigation has become the primary concern of environmental protection; whereas, due to the scarcity of natural resources (especially fossil resources) the transformation of economy, in fact, is the only solution to ensure its continuity. The author recognises that the EU ETS directly addresses both environmental dimension and economic dimension of the sustainable development. Moreover, indirectly the EU ETS might also influence the social dimension of the sustainable development, i.e. any changes in technologies might trigger changes with respect to employees using it (qualitative changes or quantitative changes, including, changes in the number of employees) as well as changes in the consumption of their products and therefore it can influence society in general.

The EU ETS is an internationally developed regional "cap and trade" type of a tradable permits system because of an absolute cap on the amount of emissions and ability to trade permits (EUAs) under the cap, keeping in mind a requirement that the amount of EUAs which corresponds to the cap must be surrendered or else penalty shall apply. The primary stimulus for GHG emission reduction is a deficiency of EUAs so, in order to assess the impact of the EU ETS on the sustainable development of its participants, the author will, first of all, determine if the EU ETS provides any stimulus for GHG emission reduction. In addition, the author will identify if a given participant of the EU ETS has traded EUAs because that could generate additional revenues to be invested to ensure the sustainable development. Then, if it is established that the EU ETS provides any stimulus for GHG emission reduction or the EU ETS participant has performed EUA trading, the assessment of the actual GHG emissions and value of fixed assets of the EU ETS participants performing EUAs trading and the EU ETS participants not performing EUA trading will be performed. In addition, with respect to the economic dimension of the sustainable development the author will also consider the amount of profits, but with respect to the social dimension of the sustainable development - the changes in the number of employees.

The EU ETS operation is structured into partly linked trading periods. Within the $1^{\text {st }}$ period (from 2005 to 2007) at least 95\% permits (EUAs) and within the $2^{\text {nd }}$ period (from 2008 to 2012) at least $90 \%$ EUAs were allocated to its direct participants free of charge, but within the $3^{\text {rd }}$ period (from 2013 to 2020) about half of all EUAs will be auctioned ${ }^{11}$. Considering the differences between the conditions of the EU ETS in force in different years, the author will analyse the available data concerning every year in a period between 2005 and 2010. 


\section{The EU ETS and the Sustainable Development of its Participants in Latvia}

Since 200578 companies and 1 municipal agency ${ }^{12}$ from Latvia have participated in the EU ETS. $42 \%$ or 33 companies that ever have participated in the EU ETS in Latvia are from the energy sector, including all largest energy sector companies. Equal number of companies come from the industry sector, including the leading producers of cement, glass, bricks, iron and stee ${ }^{13}$. The remaining companies are from agriculture, water management, trade, construction and property management sectors.

With respect to 10 companies participating in the EU ETS the results of the assessment of their sustainability pursuant to the methodology of DJSI are available. One company (JSC Latvenergo) has belonged to a "gold group" (the total sustainability index 80-89.9\%) since 2012 and 6 companies (Ltd. Cemex, JSC Daugavpils siltumtikli, Ltd. Fortum Jelgava, JSC Rigas siltums, JSC Valmieras piens, JSC Valmieras stikla skiedra) were included in a "silver group" (the total sustainability index 60-79.9\%) in 2012. It is important to mention that since 2010 three out of these 6 companies have significantly increased their sustainability, i.e. initially they were in a "bronze group" (the total sustainability index 40-59.9\%). For 2 companies (JSC Latvijas finieris and JSC Latvijas gaze) only 2010 data are available while in case of 1 company (JSC Balticovo) - just the data concerning 2010-2011 could be found. During these years all these companies were included in the "silver group" 14 . Considering the principles of the assessment, the author is of an opinion that in other years the assessment of the sustainability of these companies and the rest of the participants of the EU ETS from Latvia was either not performed or it was performed but the estimated sustainability index was below $40 \%$ and therefore the results were not published. Nonetheless, the author recognises that the available data on the sustainability of 10 companies are insufficient for the assessment of the EU ETS impact on its participants because the data row is too short (only three years at most) and too general (no information available about particular values of the sustainability index and no information about its components). Therefore, for the purpose of this analysis with respect to the EU ETS participants from Latvia the author will examine specific indicators selected above.

The total free-of-charge allocations of EUAs in Latvia in 2005-2010 (the majority of EUAs were allocated to energy sector companies (on average 61\% from total)) in general are considerably larger than the verified GHG emissions thus resulting in significant surpluses of EUAs. In the $1^{\text {st }}$ period Latvian participants of the EU ETS needed only about $65 \%$ of EUAs that were allocated to them free-of-charge, but in the first part of the $2^{\text {nd }}$ period - about $70 \%$ of EUAs. However, at the same time there are also some companies which did not receive 
a sufficient number of EUAs, e.g. 3 companies had the actual deficits of EUAs in the $1^{\text {st }}$ period. The author acknowledges that, considering large surpluses of free-of-charge allocated EUAs, for the majority of its participants in Latvia the EU ETS is an opportunity to gain additional profits by selling surpluses of EUA; what is more, for some companies the EU ETS provides also direct stimulus for GHG emission reduction.

According to the research done by the author, within the $1^{\text {st }}$ period the EU ETS participants from Latvia sold 3,313,534 EUAs and purchased 638,150 EUAs. Transactions of EUAs were performed by 45 companies (taking into account mergers and acquisitions). Half of the transactions (50\%) was performed by energy sector companies. But in terms of the size of sale transactions and the amount of revenues from EUA trading, energy sector companies by far were the leading ones (67\% and $73 \%$ accordingly). The total value of transactions in 2005 2007, according to the author's estimations, was 70,022,383 EUR (61,979,981 EUR for EUAs sold and 8,042,402 for EUAs purchased) and total income was 53,937,579 EUR. Therefore, assuming that the proportion of surplus EUAs sold in 2008-2010 is similar to the proportion of EUAs sold in $2005-2007$, i.e. $~ 60 \%$, the total volume of sales in 2008-2010 could be more than 2.0 million of EUAs which - sold at each year's average price (22.63 EUR in 2008, 14.00 EUR in 2009 and 14.76 EUR in 2010) - could have generated proceeds of more than 36 million EUR. So, the total value of total surplus EUAs in 2008-2010 valued at each year's maximum prices (31.77 EUR in 2008, 16.65 EUR in 2009 and 16.84 EUR in 2010) would be more than 75 million EUR. The author acknowledges that the total sum of actually and assumingly earned proceeds is significant and might have been used by the companies towards ensuring their sustainable development.

The total amount of GHG emissions from the EU ETS participants in Latvia in 2006 was slightly larger than in 2005. Afterwards, till 2009, GHG emissions decreased (especially between 2008 and 2009), followed by a sharp increase in 2010.

When analysing the GHG emissions of those EU ETS participants which in 2005-2007 performed EUA trading and those which did not perform EUA trading, some differences can be observed (Figure 2). The correlation coefficient between the total amounts of GHG emissions of the EU ETS participants performing EUA trading and the EU ETS participants not performing EUA trading is 0.7049 . The author acknowledges that since the trend of GHG emissions in these two groups of the EU ETS participants is not fully identical and in 2006-2009 greater GHG emission reductions were achieved by the EU ETS participants performing EUA trading, the EU ETS might have promoted reductions in the GHG emissions. Moreover, $79 \%$ of respondents in the survey answered that the EU ETS has either slightly or significantly promoted the GHG 
emission reduction in their company. Thereby, the author concludes the EU ETS might have promoted the improvements in the environmental dimension of the sustainable development of its participants in Latvia.

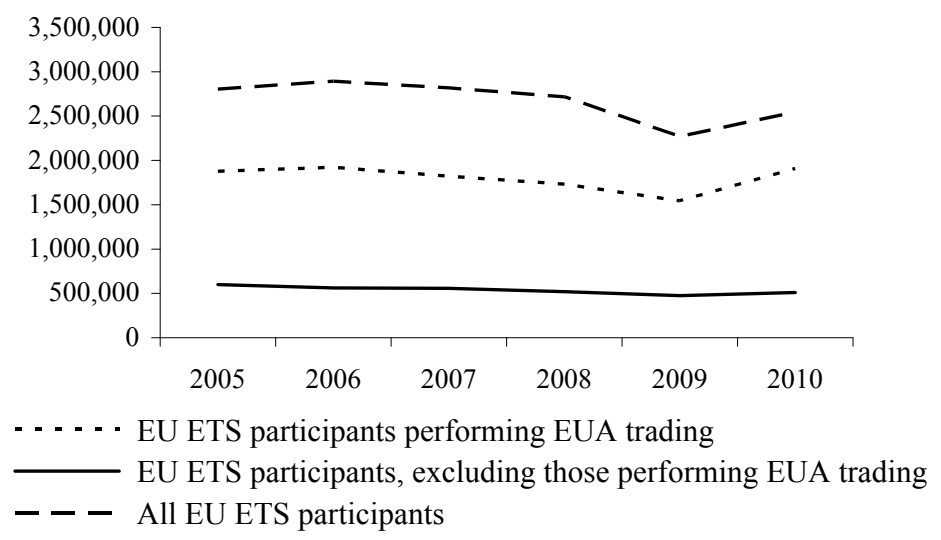

Fig. 2. Amounts of GHG emissions of the EU ETS participants in Latvia (the EU ETS participants which were not the participants of the EU ETS in every year in between 2005-2010 are excluded)

Source: created by author based on data from CTL.

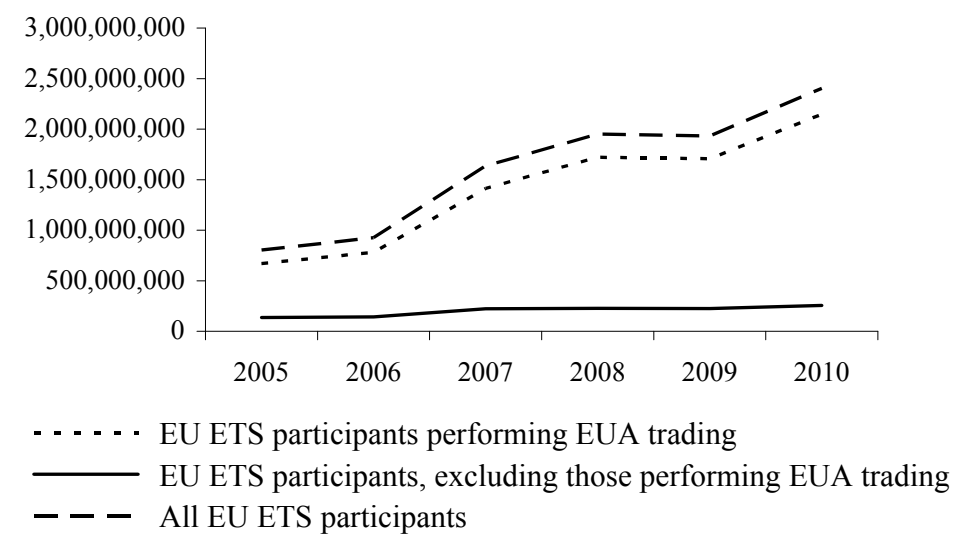

Fig. 3. Values of fixed assets of the EU ETS participants in Latvia (the EU ETS participants which were not the participants of the EU ETS in every year in between 2005-2010 are excluded)

Source: created by author based on data from Lursoft. 
The total values of the fixed assets of the EU ETS participants in Latvia since 2005 significantly increased - especially between 2006 and 2007 as well as between 2009 and 2010 (Figure 3). This is also supported by the fact that the age of the oldest technological equipment within a period 2005-2010 was reduced in case of 17 installations (the average decrease in the age of a particular technological equipment is 27 years) and, the age of the newest technological equipment was reduced in case of 41 installations (the average decrease in age of a particular technological equipment is 13 years ${ }^{15}$. Moreover, only 3 out of 35 respondents did not name any measure implemented during 2005-2010 with respect to the reduction of the GHG emission. More than half of all the respondents answered that they had made some improvement to their technologies (54\%). $46 \%$ of respondents answered that they had made some changes in their technologies, $46 \%$ had insulated heating mains and $43 \%$ - had innovated their production or other processes. Many also indicated that they had switched to other fuel (29\%), had insulated their buildings (26\%) and had changed/ improved technologies \& switched to other fuel $(20 \%)$.

When comparing values of fixed assets of the EU ETS participants in Latvia that traded EUA in 2005-2007 and the EU ETS participations that did not do so, it can be observed that although the scale of variation of fixed assets total values is very different, the trends of the dynamics of the fixed assets total values are almost identical for the EU ETS participants trading EUA and the non-trading EU ETS participants (correlation coefficient is 0.977). The author acknowledges that there is no significant evidence that the EU ETS might have promoted investments in fixed assets; hence, as described above, there are very clear examples of investments in technological equipment.

The sums of total profits of the EU ETS participants in Latvia between 2005 and 2010 fluctuated considerably and after a very sharp fall between 2006 and 2009 (by more than 80\%) in 2010 they returned to a level that is slightly above the level of 2005 (Figure 4).

The correlation coefficient between the total sums of profits of the EU ETS participants performing EUA trading and the EU ETS participants not performing EUA trading is insignificant, i.e. $|-0,328|$. The EU ETS participants performing EUA trading experienced smaller decrease of profits as well as demonstrated quicker recovery. However, it is important to note that the almost half of all EU ETS participants performing EUA trading are energy sector companies and that they provide their products to a rather inflexible market. The author acknowledges that although pursuant to the results of the quantitative analysis the EU ETS might have ensured more stable and higher profits, with due regard to the areas of operation of the EU ETS participants performing EUA trading, the participation in the EU ETS might not be the primary cause for that. 


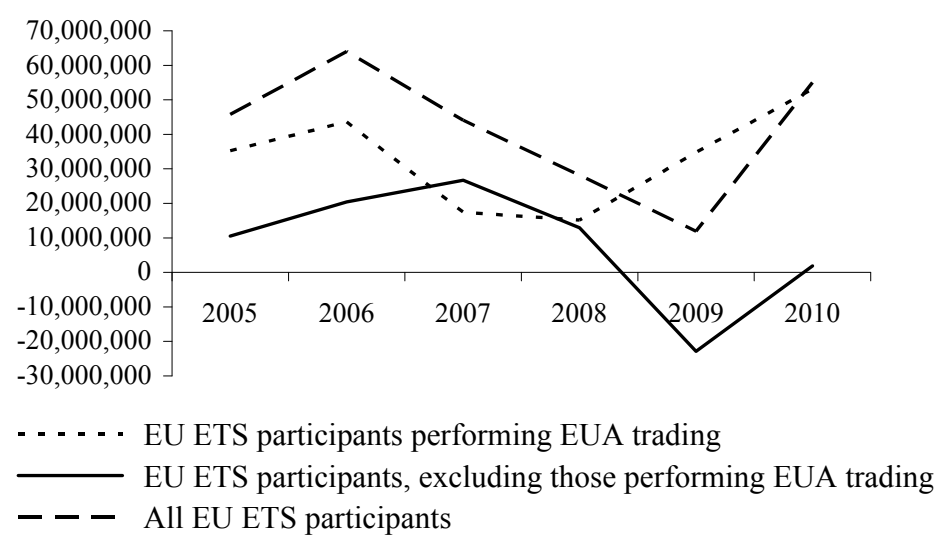

Fig. 4. Sums of total profits of the EU ETS participants in Latvia (the EU ETS participants which were not the participants of the EU ETS in every year in between 2005-2010 are excluded)

Source: created by author based on data from Lursoft.

The number of employees of the EU ETS participants in Latvia was steadily decreasing between 2005 and 2010 (except between 2005 and 2006). The total decrease in the number of employees of the EU ETS participants in Latvia was more than 30\% (Figure 5).

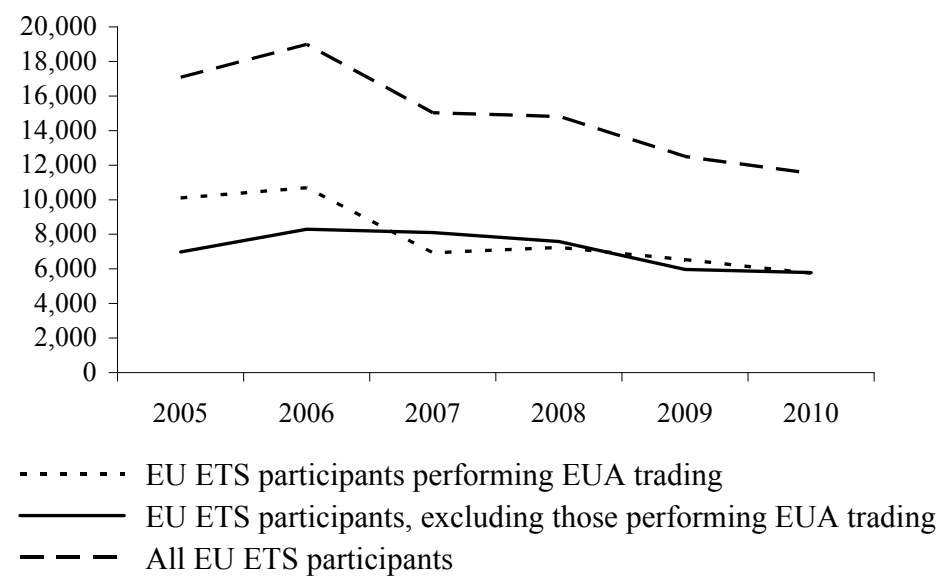

Fig. 5. Number of employees of the EU ETS participants in Latvia (the EU ETS participants which were not the participants of the EU ETS in every year in between 2005-2010 are excluded)

Source: created by author based on data from Lursoft. 
The correlation coefficient between the total number of employees of the EU ETS participants performing EUA trading and the EU ETS participants not performing EUA trading is 0.57 i.e. there is evidence that the participation in the EU ETS might have an impact on the number of employees. However, at the same time the results of the survey suggest the complete opposite, i.e. all the respondents who answered to this question indicated that the EU ETS had not affected the number of employees and some ( 2 respondents) even said that due to the EU ETS the number of its employees had slightly increased. The author concludes that although there is evidence suggesting that the participation in the EU ETS may have been related to the decrease in the number of employees, in fact, there is no significant link between those two.

\section{Conclusions}

1. The EU ETS has a potential of influencing the sustainable development of its participants and it might have an impact on all three dimensions of the sustainable development, i.e. the environmental, social and economic ones.

2. In Latvia the EU ETS is influencing the sustainable development of its participants by means of providing an opportunity to gain additional financial resources.

3. The EU ETS may have promoted the improvements in the environmental dimension of the sustainable development of its participants in Latvia, although that is not clearly supported by the analysis of the data of values of fixed assets.

4. The EU ETS may have promoted the improvements in the economic dimension of the sustainable development of its participants in Latvia, however, in order to fully confirm it, it is necessary to analyse the financial data of the EU ETS participants in Latvia in a more detailed way.

5. There is highly contradictory information with respect to the possible impact of the EU ETS on the social dimension of the sustainable development of its participants in Latvia; therefore, in order to draw any conclusions with respect to that it is necessary to extend the scope of the respective analysis.

\section{Notes}

1 Kossoy, Guigon (2012).

2 Judgment of the General Court of 22 March (2011).

3 United Nations (1987). 
4 Ibidem.

5 Council of the European Union (2006).

6 Eurostat (2009).

7 Puri, Gaye, Kurukulasuriya, Scott (2007)

8 Yale Center for Environmental Law and Policy, Yale University \& Center for International Earth Science Information Network, Columbia University (2012).

9 Dow Jones Indexes (2007).

${ }^{10}$ Directive 2003/87/EC (2003).

${ }^{11}$ Ibidem.

12 Data from CTL.

${ }^{13}$ Data by Lursoft.

${ }^{14}$ Data from Ilgtspçjas indekss $(2010,2011,2012)$.

${ }^{15}$ Data from LVGMC.

\section{References}

Accounts. (2011). Community Transaction Log, http://ec.europa.eu/environment/ ets/account. do?languageCode $=\mathrm{en}(20.12 .2011)$.

Allocation/Compliance. (2011). Community Transaction Log, http://ec.europa.eu/ environment/ets/allocationComplianceMgt.do?languageCode=en (20.12.2011).

Consolidated version of Directive 2003/87/EC of the European Parliament and of the Council of 13 October 2003 Establishing a Scheme for Greenhouse Gas Emission Allowance Trading Within the Community and Amending Council Directive 96/61/EC, OJ L 275, 25.10.2003 [with amendments until 23 April 2009], http://eur-lex.europa.eu/LexUriServ/ LexUriServ.do?uri=CONSLEG:2003L0087:20090625:EN:PDF (1.08.2012).

Council of the European Union (2006, June 26). Renewed EU Sustainable Development Strategy as adopted by the European Council on 15/16 June 2006, http://register.consilium. europa.eu/pdf/en/06/st10/st10917.en06.pdf (1.08.2012).

Dow Jones Indexes (2007). Dow Jones Sustainability Europe Indexes Guide Book: Version 1.4, from www.sustainability-indexes.com/images/djsi-europe-guidebook_tcm1071-337250. $\operatorname{pdf}(1.08 .2012)$.

Eurostat (2009), Sustainable development in the European Union: 2009 monitoring report of the EU sustainable development strategy. Belgium: Eurostat.

Ilgtspejas indekss 2010 (2010). Supplement to the journals "Diena" and "Dienas Bizness", www.slideshare.net/llgtspeja/ilgtspjas-indekss-prskats-2010 (25.08.2012).

Ilgtspejas indekss 2011 (2011). Supplement to the journals "Diena" and "Dienas Bizness", www.slideshare.net/Ilgtspeja/ilgtspjas-indeksa-prskats-2011 (25.08.2012). 
Ilgtspejas indekss 2012 (2012). Supplement to the journal "IR", www.slideshare.net/Ilgtspeja/ ilgtspjas-indeksa-prskats-2012 (25.08.2012).

Judgment of the General Court of 22 March 2011 - Republic of Latvia v Commission (Case T-369/07), Official Journal of the European Union, C 139/15, 7.05.2011.

Kossoy, A. \& Guigon, P. (2012). State and Trends of the Carbon Market 2012. Washington: The World Bank.

Latvian Environment, Geology and Meteorology Centre. National GHG emission quota register - Reports on GHG Emissions prepared by EU ETS operators, www.meteo.lv/public/ SEG_registram.html (20.12.2011).

Lursoft. Companies registered in Latvia, http://www.lursoft.lv (20.12.2011).

Point Carbon. EUA OTC Assessment, www.pointcarbon.com/news/ marketdata/euets/forward/ eua/ (20.12.2011).

Puri, J., Gaye, A., Kurukulasuriya S. \& Scott T. (2007). Measuring Human Development. New York: United Nations Development Programme.

Spangenberg, J.H. (2004, May). Sustainability Beyond Environmentalism: the Missing Dimensions. GoSD Working Paper No. 2.

Transactions. (2012). Community Transaction Log, http://ec.europa.eu/environment/ets/ transaction.do?languageCode=en (1.03.2012).

United Nations (1987). Report of the World Commission on Environment and Development: Our Common Future - Transmitted to the General Assembly as an Annex to document A/42/427, UN, www.un-documents.net/ (1.08.2012).

Yale Center for Environmental Law and Policy, Yale University \& Center for International Earth Science Information Network, Columbia University. (2012) Environmental Performance Index and Pilot Trend Environmental Performance Index - EPI 2012, http://epi. yale.edu/sites/default/files/downloads/2012-epi-full-report.pdf (1.08.2012). 